\title{
Experimental Study on Interception Efficiency of Receptor on Wind Turbine Blade with Brine Adhesion
}

\author{
Wanshui Yu \\ State Key Lab of Alternate Electrical \\ Power System with Renewable Energy \\ Sources \\ North China Electric Power University \\ Beijing, China \\ yws@necpu.edu.cn \\ Yufei Ma \\ State Key Lab of Alternate Electrical \\ Power System with Renewable Energy \\ Sources \\ North China Electric Power University \\ Beijing, China \\ 15652912154@163.com \\ Wah Hoon Siew \\ Department of Electronic \& Electrical \\ Engineering \\ University of Strathclyde \\ Glasgow, United Kingdom \\ wh.siew@strath.ac.uk
}

\author{
Minhao Zhang \\ State Key Lab of Alternate Electrical \\ Power System with Renewable Energy \\ Sources \\ North China Electric Power University \\ Beijing, China \\ mhzhang0317@163.com \\ Waqas Arif \\ State Key Lab of Alternate Electrical \\ Power System with Renewable Energy \\ Sources \\ North China Electric Power University \\ Beijing, China \\ waqasarif@qq.com
}

\author{
Zixin Guo \\ State Key Lab of Alternate Electrical \\ Power System with Renewable Energy \\ Sources \\ North China Electric Power University \\ Beijing, China \\ guozixin@ncepu.edu.cn \\ Qingmin Li \\ State Key Lab of Alternate Electrical \\ Power System with Renewable Energy \\ Sources \\ North China Electric Power University \\ Beijing, China \\ lqmeee@ncepu.edu.cn
}

\begin{abstract}
Lightning creates a huge threat to offshore wind turbine due to its height and the marine environment. The blade surface will be polluted by brine after long operation in highsalinity and high-humidity environment. In order to study the efficiency of the receptor under the influence of brine covered on blade surface, a group controlled test is conducted in this paper. Statistical analysis is applied according to the test results. The results show that, the adhesion of brine on the blade surface reduces the interception efficiency of receptor greatly, which makes the blade exposed to a huge threat of lightning damage. Only water or salt has limited impact compared with brine. The influence of the brine area is more obvious if the area is close to the receptor. It can expand the severe area of strike and reduce the interception efficiency of the receptor. The brine area far from the receptor has a limited effect on attracting downward leader.
\end{abstract}

Keywords- wind turbine blade, brine adhesion, receptor, interception efficiency, lightning protection

\section{INTRODUCTION}

In recent years, wind power generation has developed rapidly, and has a broad prospect in the future. However, the development of large-scale wind turbines meets challenges from lightning. According to field observations, 2-3 blade damage events occur during the wind turbine lifetime of 20 years [1]. It is a trend that wind power generation develops toward offshore area. But offshore wind turbines are more likely to be struck by lightning. On the on hand, the turbines are usually located in open environment, with high towers and long wind turbine blades. One the other hand, the blades of offshore wind turbines are prone to be adhered with brine after long-time exposure in the marine-atmosphere environment, which will reduce the efficiency of the lightning protection system.

Some experiments have been conducted on the specimen of real wind turbine blade to improve the design of the lightning protection system [2]-[4]. But the experiments have poor repeatability as they are usually destructive to the specimens and it is difficult to obtain enough specimens. Moreover, the salt factor is not taken into consideration in these experiments.

The research carried by Douar [5] indicated that pollution deposit on the surface of insulator reduces the flashover voltage, irrespective of the polarity of applied voltage. Kumar [6] found that the flashover voltage reduced with the increase of the salt deposit density on the glass fiber reinforced plastic (GFRP) material. Holboell [7] found that wet polluted surface of blade had an increasing tendency of streamer attraction. Montanya[8] found as the blade becomes polluted initial lateral leaders appears before the breakdown to ground. However, the influence of brine adhering in different manners on the distribution of lightning attachment points is not clear. 
In this paper, a simplified blade model is applied. Controlled test is conducted to explore the effect of brine to the interception efficiency of the receptor on blade.

\section{EXPERIMENTAL WORK}

\section{A. Simplified model of wind turbine blade}

The Les Renardieres Group proposed that the natural lightning discharges showed some similarities with the laboratory long gap discharges based on the experimental studies [9]-[10].

To ensure enough generating capacity of one single wind turbine, the length of offshore wind turbine blade is usually over 45 meters. Comparing the scale of lightning evolution and the size of wind turbine blade, assume that the shape of blade has no effect on lightning attachment. In this paper, a simplified model of wind turbine blade is adopted as shown in Fig. 1.

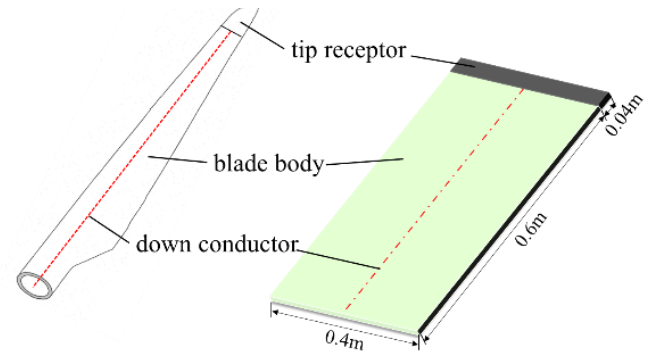

Figure 1. Simplified model of wind turbine blade

The test specimen consists with a glass fiber reinforced plastic(GFRP) board $60 \mathrm{~cm} \times 40 \mathrm{~cm} \times 1 \mathrm{~cm}$ as blade body, a aluminum-made panel $40 \mathrm{~cm}$ by $4 \mathrm{~cm}$ with a thickness of $1 \mathrm{~cm}$ as tip receptor, an aluminum wire adhering to the back side of the board as down conductor. The down conductor and the tip receptor are bolted together.

\section{B. Experiment setup}

Place the specimen on the insulating support horizontally, with its down conductor connecting to ground. A rod electrode fixed 0.6 meter above the middle of the specimen is connected to an impulse voltage generator(Fig. 2).
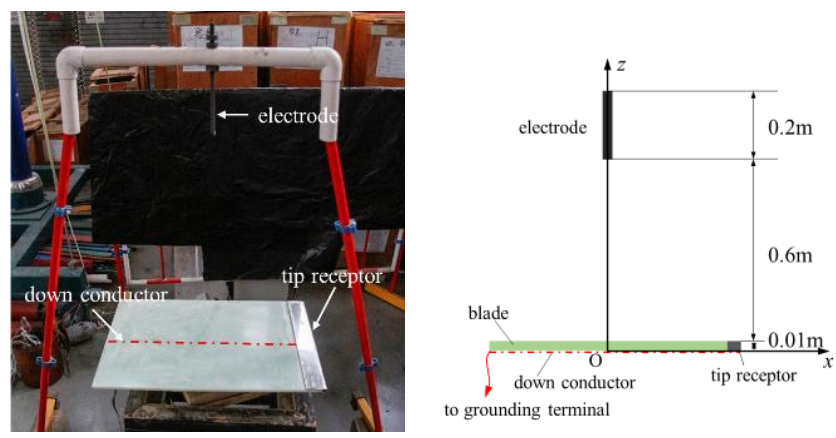

(a) photograph of experiment platform (b) sketch of experiment platform

Figure 2. Front view of experiment platform

To simulate the natural lightning downward leader, the $1.2 / 50 \mu$ s lightning impulse is adopted as testing waveform. In this paper, five groups of impulse voltage test under positive

This project is supported by National Natural Science Foundation of China (51420105011). polarity are conducted. Perform 15 times impulse voltage experiments in each case.

(1) Impulse test on the specimen with clean and dry surface;

(2) Impulse test on the specimen covered with evenlydistributed water on its surface;

(3) Impulse test on the specimen covered with evenlydistributed brine film;

(4) Impulse test on the specimen covered with crystalloid salt;

(5) Impulse test on the specimen with dry and brine areas.

Group (1) is a control group. Group (2) and (4) are set to discover the influence of sigle factor, pure water and salt crystal, respectively, while group (3) is set to study the interception efficiency of receptor in marine environment. In order to find the impact of brine coverd near the receptor on blade surface, group (5) is set. Because of the hydrophobicity of GFRP, water can not easily cover on blade surface. Therefore, in test (2) and (3), before adhering water or brine on the specimen, firstly use kieselguhr to destroy its hydrophobicity. According to IEC 60507 [11], saline pollution is applied on specimen surface. To simulate the marine environment, salinity of $35 \mathrm{~g} / \mathrm{L}$ is used in the tests. In test (4), use the same method to form saline film shown in test (3), and place the specimen under laboratory conditions until the brine entirely transfer to salt crystals. In test (5), the dry and brine areas are divided as shown in Fig. 3. Every brine area is $0.2 \mathrm{~m}$ meter wide. Saline area $\mathrm{I}$ is close to the tip receptor. And saline area II is on the left of the specimen, without touching any metal part. Boundary I represents the boundary of saline area I and dry area, while boundary II the boundary of saline area II and dry area.

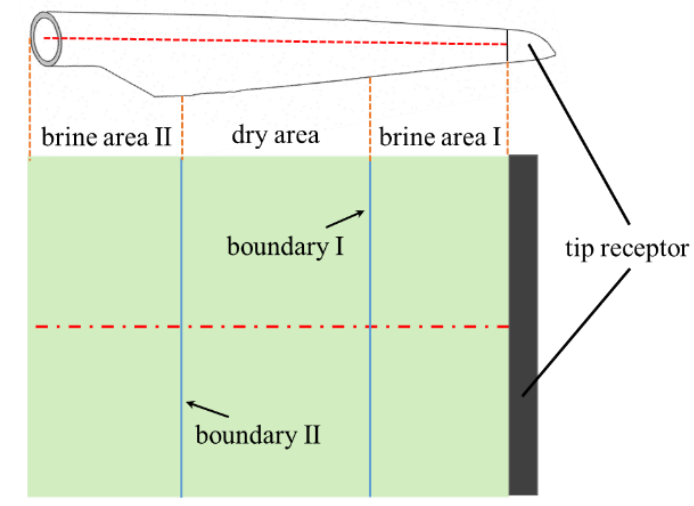

Figure 3. Schematic diagram of area partition on the specimen

\section{EXPERIMENT RESULTS}

Statistical analysis is conducted according to the 5 group tests. Table. I illustrates the interception efficiency of the receptor under different conditions of specimen surface.

TABLE I. ATTACHMENT RESULTS OF BLADE UNDER SWITCHING IMPULSE EXPERIMENT

\begin{tabular}{cccccc}
\hline $\begin{array}{c}\text { Test } \\
\text { Group }\end{array}$ & $\begin{array}{c}\text { Surface } \\
\text { condition }\end{array}$ & Total & $\begin{array}{c}\text { Success } \\
\text { total }\end{array}$ & $\begin{array}{c}\text { Failure } \\
\text { total }\end{array}$ & $\begin{array}{c}\text { Interception } \\
\text { efficiency }\end{array}$ \\
\hline A & $\begin{array}{c}\text { Clean and } \\
\text { dry }\end{array}$ & 15 & 10 & 5 & $66.7 \%$ \\
B & $\begin{array}{c}\text { With water } \\
\text { film }\end{array}$ & 15 & 8 & 7 & $53.3 \%$ \\
\hline
\end{tabular}




\begin{tabular}{|c|c|c|c|c|c|}
\hline $\mathrm{C}$ & $\begin{array}{l}\text { With brine } \\
\text { film }\end{array}$ & 15 & 0 & 15 & 0 \\
\hline D & $\begin{array}{l}\text { With salt } \\
\text { crystal }\end{array}$ & 15 & 10 & 5 & $66.7 \%$ \\
\hline E & $\begin{array}{l}\text { With dry } \\
\text { and brine } \\
\text { areas }\end{array}$ & 15 & 1 & 14 & $6.7 \%$ \\
\hline
\end{tabular}

Detailed results are shown as follows.

\section{A. Specimen with clean surface}

In one attachment of lightning strike, if the discharge reaches straight the receptor, it is a successful interception of the receptor, if the discharge sweeps the blade surface instead, it is a failing interception.

There are 10 times interception successes in this case. Fig. 4 shows two typical discharge channels with this setup. The receptor is hit by downward leader and makes blade body safe, as shown in Fig. 4(a). If downward leader strikes on blade body, the discharge will find a metal channel in order to lead the energy to ground. Fig. 4(b) shows a case of interception failure. The discharge channel connects with the down conductor, with creeping arc on blade body.

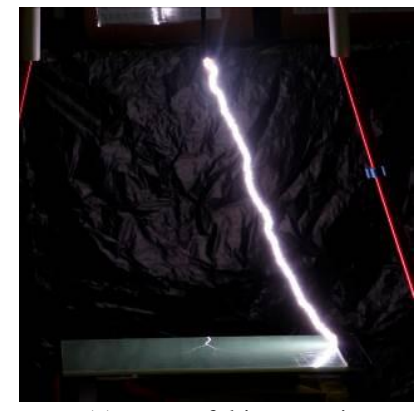

(a) successful interception

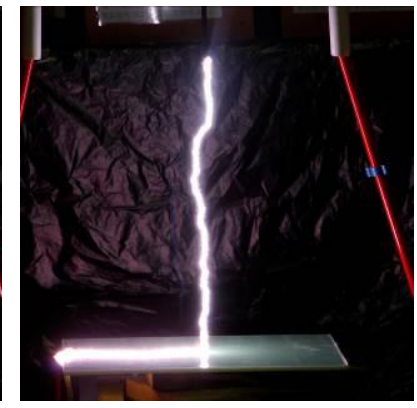

(b) failing interception
Figure 4. Typical discharge channels on clean blade

Statistical analysis is conducted according to the experimental photographs. Fig. 5 shows the distribution of attachment points in this case. Symbol " $x$ " represents the attachment points on the blade. The distribution of failing interception points on specimen surface follows the setup manner of down conductor, as shown in dotted box in Fig. 5. In fact, not only the down conductor, other conducting components affect the field, such as sensors or electronic devices installed in the blade for measuring purposes [12]. Thus, a reasonable setup of down conductor in the structure of blade should be taken into consideration.

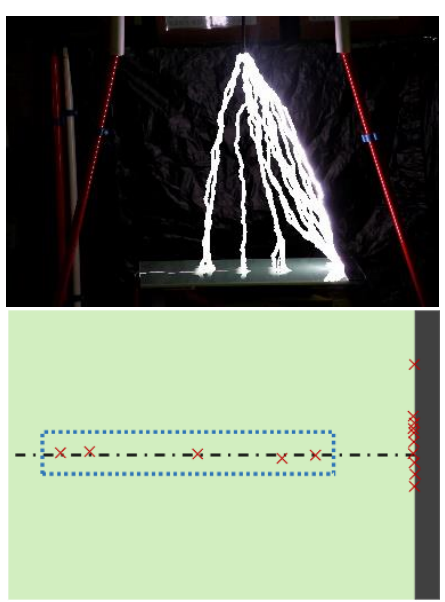

Figure 5. Distribution of attachment points on clean blade

\section{B. Specimen with evenly-distributed water film}

Fig. 6 shows two typical discharge channels in this case. The downward leader finally connects with the arc incepted from the down conductor near the broadside of the specimen, as shown in Fig. 6(b).

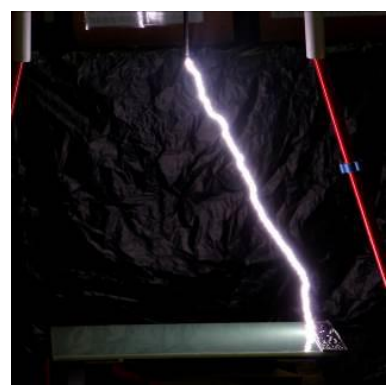

(a) successful interception

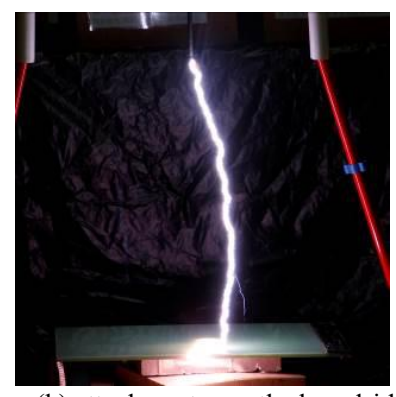

(b) attachment near the broadside
Figure 6. Typical discharge channels on blade with water film

The failing interception points are more dispersive as shown in the red area of Fig. 7, and the down conductor of blade has less influence on their distribution.

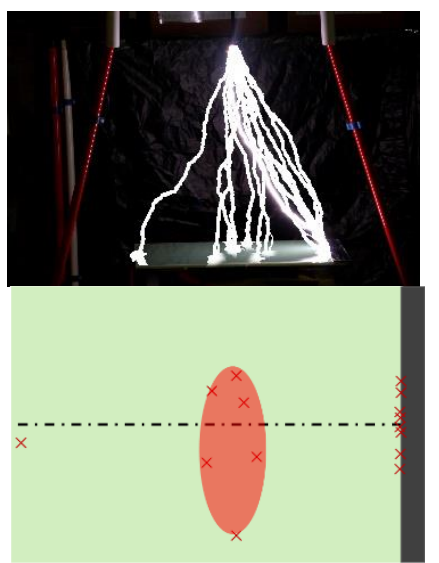

Figure 7. Distribution of attachment points on blade with water film

\section{Specimen with evenly-distributed brine film}

There is no successful interception in this case. All downward leaders strike on the blade surface. The discharge can cause severe creeping discharges, as shown in Fig. 8(a), or more than one attachment point, as shown in Fig. 8(b), which may cause huge damage to blade in actual operation.
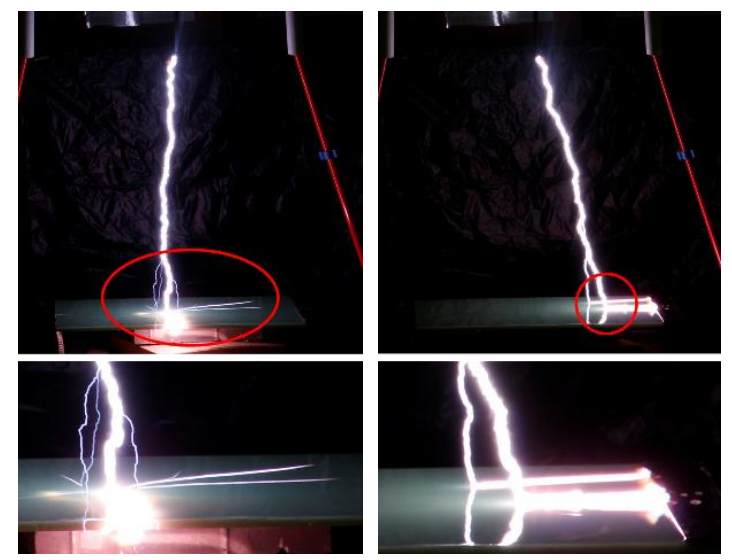

(a) creeping discharges on the specimen (left) 
Figure 8. Severe discharge cases

The main attachment area focuses between the center and the receptor of blade, as shown in the red circle in Fig. 9. Receptor fails to intercept downward leader due to the brine adhesion. After long-time operation in marine environment, the hydrophobicity on the surface of wind turbine blade is destroyed so that the blade will be easily adhered with brine film, which will make the failure of the receptors on blade once lightning strike occurs.

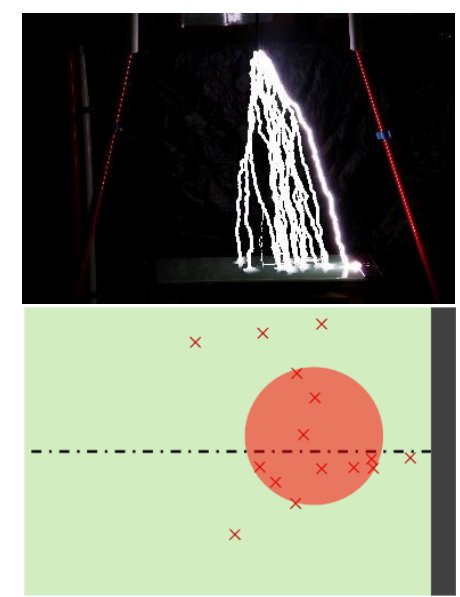

Figure 9. Distribution of attachment points on blade with brine film

\section{Specimen with crystalloid salt film}

To explore the influence of salt crystal on the interception of receptor, this group experiment is conducted. The discharge paths show no much difference compared with section III. A. From Fig. 10, it can be seen that the distribution of failing attachment points is similar with the case of water-film. The adhesion of salt crystal can also reduce the impact of down conductor, making attachments more dispersive.
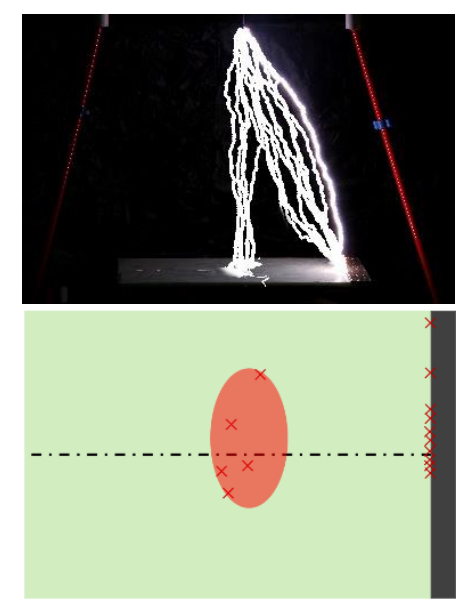

Figure 10. Distribution of attachment points on blade with salt crystal

\section{E. Specimen with dry and brine area}

As shown in TABLE II, lightning discharges strike on receptor, saline area I, boundary I and boundary II once, 6 times, 6 times and twice, constituting 6.7\%, 40\%, 40\% and $13.3 \%$ of the total lightning discharges, respectively.
TABLE II. ATTACHMENT RESULTS WITH THE SETUP OF SALINE AND DRY AREAS

\begin{tabular}{cccccc}
\hline Total & $\begin{array}{c}\text { Strike } \\
\text { on } \\
\text { receptor }\end{array}$ & $\begin{array}{c}\text { Strike } \\
\text { on } \\
\text { saline } \\
\text { area } \\
\text { I }\end{array}$ & $\begin{array}{c}\text { Strike on } \\
\text { boundary } \\
\text { I }\end{array}$ & $\begin{array}{c}\text { Strike on } \\
\text { boundary }\end{array}$ & $\begin{array}{c}\text { Interception } \\
\text { efficiency }\end{array}$ \\
\hline 15 & 1 & 6 & 6 & 2 & $6.7 \%$ \\
\hline
\end{tabular}

The typical discharge path of this case is shown in Fig. 11(a)-(d), respectively.
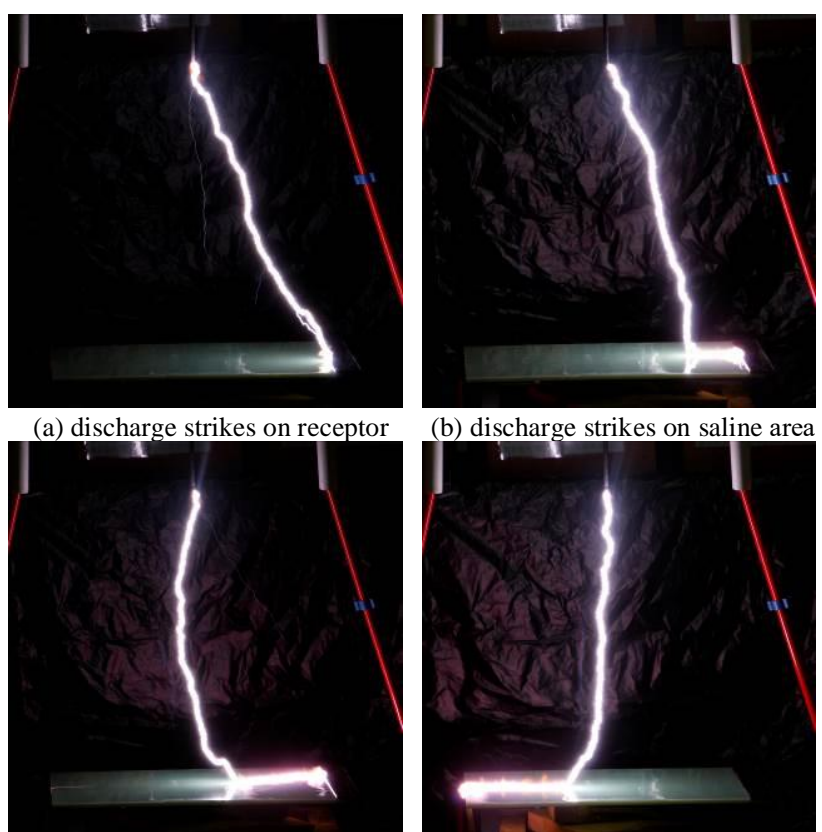

(b) discharge strikes on saline area I

(c) discharge strikes on boundary I (d) discharge strikes on boundary II

Figure 11. Typical discharge channels with the setup of saline and dry areas

Fig. 12 shows the distribution of attachment points in this case. With a certain conductivity, the brine film adhered on blade can attract downward leader like receptor. The brine area close to the receptor can expand the severe area of strike and reduce the interception efficiency of the receptor. Therefore, the attachment points mainly focus in saline area I and on the boundary of saline area I and dry area, as shown in the red area in Fig. 12.
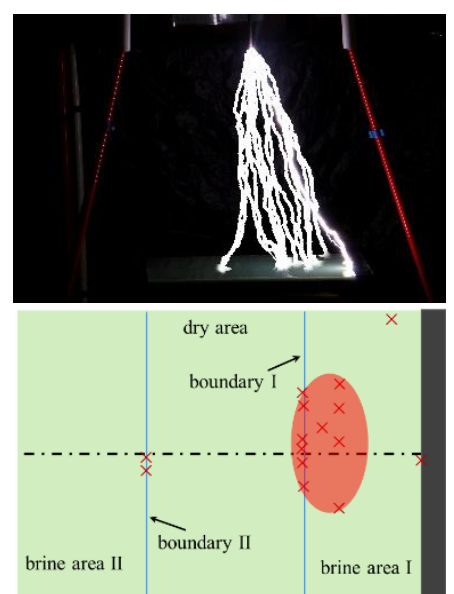

Figure 12. Distribution of attachment points on blade with the setup of saline and dry areas 


\section{DISCUSSION}

From TABLE I and the results shown in section III, the receptor in test $A$ has the highest interception efficiency, while that in test $\mathrm{C}$ has the lowest, which indicates that evenlydistributed brine film has a strong impact on lightning interception failure of blade.

Comparison of test A and test B shows that water film without salt has a weak influence on interception efficiency of the receptor.

It also can be seen that salt crystal has little influence comparing test 1 and test D.

From test E, the impact of brine area near the receptor can not be ignored. It causes the interception failure of receptor.

Therefore, the adhesion of brine film on the blade surface reduces the interception efficiency of receptor greatly, which makes the blade exposed to a huge threat of lightning damage. The brine area close to the receptor can expand the severe area of strike and reduce the interception efficiency of the receptor. The brine area far from the receptor has a limited effect on attracting downward leader.

\section{CONCLUSION}

Experimental results indicate that the receptor on a dry and clean blade can intercept downward leader effectively. But the down conductor through the blade is a potential threat when lightning strike occurs. Since down conductor is an essential component of lightning protection system of blade, reasonable setup of down conductor is important. Future research should be done in this respect.

The blade body has high probability to get struck by lightning when blade surface is covered with evenlydistributed brine film, which is caused by the synergistic effect of water and salt. Either water or salt has limited impact on interception efficiency of the receptor. So it is suggested to clean the off-shore wind turbine blade at regular intervals.

Even if the blade surface is not covered with continuous brine film entirely, the adhesion of brine area close to the receptor expands the attachment area prone to be struck by lightning. Thus, the area close to receptor is suggested to be checked and painted with hydrophobic coatings at regular intervals.

\section{REFERENCES}

[1] A. Candela Garolera, S. F. Madsen, M. Nissim, J. D. Myers and J. Holboell, "Lightning Damage to Wind Turbine Blades From Wind Farms in the U.S.," in IEEE Transactions on Power Delivery, vol. 31, no. 3, pp. 1043-1049, June 2016.

[2] Z. Guo, Q. Li, Y. Ma, W. H. Siew, C. Chen and X. Jiang, "The performance of lightning protection system of wind turbine blade - a preliminary experimental study," in the 10th Asia-Pacific International Conference on Lightning (APL-2017), Krabi, Thailand, 2017, pp. 547-552.

[3] Muto, J. Suzuki, T. Ueda, "Performance comparison of wind turbine blade receptor for lightning protection," in the 30th International Conference on Lightning Protection (ICLP-2010), Cagliari, Italy, 2010, pp. 1263-1 - 1263-6.

[4] M. A. Amr, A. S. Nehmdoh, A. I. Mohamed, "Experimental evaluation of air-termination systems for wind turbine blades,' Electric Power Systems Research, vol. 107, pp. 133-143, 2014.

[5] M. A. Douar, A. Mekhaldi and M. C. Bouzidi, "Flashover process and frequency analysis of the leakage current on insulator model under non-uniform pollution conditions," IEEE Transaction on Dielectric and Electrical Insulation, vol. 17, pp. 1284-1297, 2010.

[6] V. S. Kumar, N. J. Vasa, R. Sarathi, D. Nakamura and T. Okada, "Understanding the discharge activity across GFRP material due to salt deposit under transient voltages by adopting OES and LIBS technique," IEEE Transaction on Dielectric and Electrical Insulation, vol. 21, pp. 2283-2292, 2014

[7] J. Holboell, S. F. Madsen and M. Henriksen, " Discharge phenomena in the tip area of wind turbine blades and their dependency on material and environmental parameters," in the $28^{\text {th }}$ International Conference on Lightning Protection (ICLP-2006), Kanazawa, Japan, 2006, pp. 1503-1508.

[8] J. Montanyà, V. March, B. Hermoso and J. R. Hermoso, "High-speed videos of laboratory leaders emerging from wind turbine blade tips," 2010 30th International Conference on Lightning Protection (ICLP), Cagliari, 2010, pp. 1-5.

[9] Les Renardieres Group. Positive discharges in long air gaps-1975 results and conclusions[J]. Electra, 1977, 53: 31-132.

[10] Les Renardieres Group. Negative discharges in long air gaps[J]. Electra, 1981, 74: 67-216.

[11] IEC 60507, “Artificial Pollution Tests on High Voltage Insulators to be Used on AC-Systems", IEC 2 ${ }^{\text {nd }}$ edition, April 1991.

[12] A. C. Garolera, J. Holboell and S. F. Madsen, "Lightning Attachment to Wind Turbine Surfaces Affected by Internal Blade Conditions," in the 31th International Conference on Lightning Protection (ICLP2012), Vienna, Austria, 2012. 